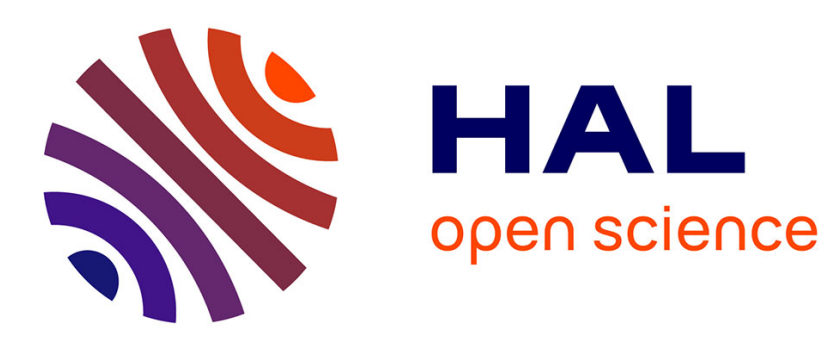

\title{
A T.E.M. in situ study of dislocation glide in InSb (III-V compound)
}

M. Fnaiech, Alain Couret, Daniel Caillard

\section{To cite this version:}

M. Fnaiech, Alain Couret, Daniel Caillard. A T.E.M. in situ study of dislocation glide in InSb (III-V compound). Revue de Physique Appliquée, 1988, 23 (4), pp.668-668. 10.1051/rphysap:01988002304066800 . jpa-00245817

\section{HAL Id: jpa-00245817 https://hal.science/jpa-00245817}

Submitted on 1 Jan 1988

HAL is a multi-disciplinary open access archive for the deposit and dissemination of scientific research documents, whether they are published or not. The documents may come from teaching and research institutions in France or abroad, or from public or private research centers.
L'archive ouverte pluridisciplinaire HAL, est destinée au dépôt et à la diffusion de documents scientifiques de niveau recherche, publiés ou non, émanant des établissements d'enseignement et de recherche français ou étrangers, des laboratoires publics ou privés. 


\section{A T.E.M. IN SITU STUDY OF DISLOCATION GLIDE IN InSb (III-V COMPOUND) \\ M. FNAIECH, A. COURET, D. CAILLARD}

Groupe de Déformation Plastique - Laboratoire d'Optique Electronique du CNRS

29 rue Jeanne Marvig, BP 4347, 31055 TOULOUSE CEDEX, France

Tensile microsamples are cut out of samples predeformed up to the lower yield point. They are oriented for single glide, with respective Schmid factors of 0.47 and 0.35 for primary and secondary glide systems.

Several dislocation sources are observed at $180^{\circ} \mathrm{C}$, which emit screw and $\beta$ type $60^{\circ}$ dislocations, submitted to a strong Peierls force, and much more rapide $\alpha$-type $60^{\circ}$ dislocations $|1|$ (Fig. 1).
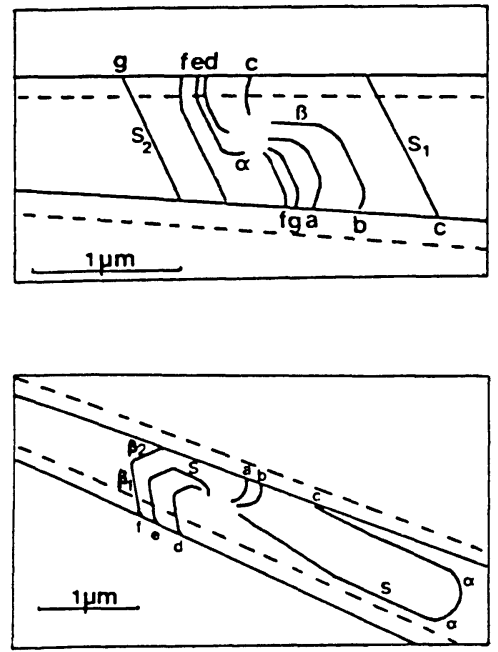

Fig. 1 - Scheme of dislocation sources (1 and 2) observed in situ.

There is no (or almost no) effect of the electron beam on the velocity of dislocations (cathodo plastic effect). The velocity of dislocations, and the corresponding local shear stress, have been measured in the vicinity of sources. The velocity of $\alpha$ dislocations is more than 100 times higher than the velocity of $\beta$ and screw dislocations, and the velocity of dislocations is proportional to their length (length effect) for a constant local stress, with no indication of a maximum value in the investigated range (Fig. 2).

This means that the probability of nucleating a kink pair is proportional to the dislocation length, and that the time for kink movement along the observed dislocations is shorter than the time for kink nucleation.

No significant difference can be detected between the velocity of screws and $\beta$ dislocations, for a constant stress (Fig. 2). This tends to confirm that the velocity of "slow" dislocations should be controlled by the mobility of $30^{\circ} B$ partial dislocations.

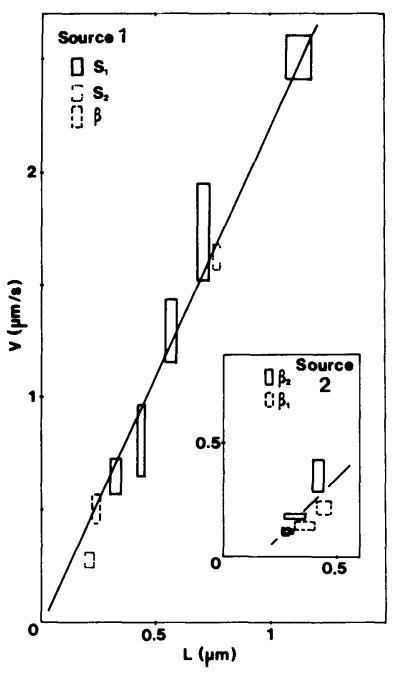

Fig. 2 - Velocity of screw and $\beta$ dislocation segments as a function of their length.

Using the following expressions for the velocity of dislocations

(1) $\quad v=\frac{\nu_{d} b^{3} L}{k T} \exp -\frac{F_{d k}^{*}+W_{m}}{k T}$

in the length effect range, and

$$
v_{M}=\frac{\nu_{d} b^{4}}{k T} \exp -\frac{\frac{1}{2} F_{d k}^{*}+w_{m}}{k T}
$$

if the velocity becomes length independent for large lengths (situation not observed here), it is possible to obtain minimum and maximum values for the energy of a double kink of critical size $\left(\mathrm{F}_{\mathrm{dk}}^{*}>.6 \mathrm{eV}\right)$ and for the kink migration energy $\left(\mathrm{W}_{\mathrm{m}}<.5 \mathrm{eV}\right)$.

The local stress being estimated as $50 \mathrm{MPa}$, our measurements are compatible with the results of double etch pit experiments, at similar temperature and lower stresses, provided simple assumptions are made. They are also compared with results obtained by the same technique in II-VI compounds, and the latter appear to behave partly as III-V compounds, and partly as metals.

More recent results obtained in GaAs with $\mathrm{N}$. Clément in collaboration with the University of Lille (Y. Androussi, A. Lefebvre, G. Vanderschave) will be also presented.

Reference :

|1| M. Fnaiech, F. Reynaud, A. Couret, D. Caillard, Phil. Mag. A55, 405 (1987). 